\title{
The alkaline rocks of the Motzfeldt Centre; progress report on the 1984 field season
}

\author{
Colin Bradshaw
}

The detailed mapping programme in the Motzfeldt Centre that commenced in 1982 with the Syduran project (Armour-Brown et al., 1983) continued in collaboration with the GGU Pyrochlore project in 1984 (Tukiainen, this report). The results obtained during the 1982 field season enabled the various syenite units of the centre to be grouped (from older to younger) into Geologfjeld (GF), Motzfeldt Sø (MSF) and Flinks Dal (FDF) Formations (Tukiainen et al., 1984). The purpose of the work in 1984 was to study the structure and spatial distribution of the rock formations in the lesser known western and southern parts of the Motzfeldt Centre. The revised map is shown in Tukiainen (this report) and some of the more important observations are outlined below.

\section{The boundary between the Geologfjeld and Motzfeldt $S \varnothing$ Formations}

Tukiainen et al. (1984) proposed that the Geologfjeld syenite is truncated downwards by the syenites of the Motzfeldt $\$ \emptyset$ Formation. In north-east Motzfeldt the boundary relations remain problematical. No clear cross-cutting relations were found, but the Geologfjeld Formation grades rapidly downwards from a white, coarse, homogeneous nepheline-free syenite into pink-brown feldspar-laminated syenite with conspicuous nepheline.

In north-west Motzfeldt the Geologfjeld syenite is of restricted occurrence. A narrow wedge ( $<400 \mathrm{~m}$ wide) is roofed by Julianehåb granite to the north and is clearly truncated by syenites of the Motzfeldt S $\varnothing$ Formation to the south. The MSF/GF contact is well exposed in places and is found to be sharp with several pegmatitic apophyses extending into the Geologfjeld syenite. Though the older syenite is stained over a $10 \mathrm{~m}$ zone, the characteristic white colour of the Geologfjeld syenite is rapidly encountered away from the contact. This suggests that the rock was consolidated and therefore essentially impervious to the volatile phase that altered and mineralised the syenite of the Motzfeldt Sø Formation (Tukiainen et al. 1984).

\section{Motzfeldt Sø Formation}

The revised distribution of syenites of this formation in western and south-western Motzfeldt Centre (fig. 19) accords well with that indicated by radiometric data (Tukiainen et al., 1984). Of particular note is the position of the MSF/FDF boundary on the north side of the Flinks Dal fault, east-central Motzfeldt, located for the first time this summer. This confirms the c. $6 \mathrm{~km}$ sinistral offset along the Flinks Dal Fault (Tukiainen, this report).

A new find was a large screen (more than $300 \mathrm{~m}$ wide) of MSF nepheline syenite contained within the Flinks Dal Formation syenite which is chilled against the Motzfeldt Sø Formation syenite. The screen is located in the high ground $3 \mathrm{~km}$ NNE from the south-east corner of Motzfeldt Sø.

Most of the ground in south-central Motzfeldt Centre, adjacent to and south of the Flinks Dal fault, is provisionally ascribed to the Motzfeldt $§ \varnothing$ Formation, because the field evidence 
demonstrates that it is made up of a variety of syenites which are older than the Flinks Dal Formation. It is possible that the syenites here represent the inner facies of the Motzfeldt $\$ \emptyset$ Formation, or that they contain partially assimilated material from the Geologfjeld Formation. The classification of the syenite types remains to be solved by geochemical studies.

\section{Flinks Dal Formation}

Recent evidence suggests that the foyaite of south-east Motzfeldt Centre is considerably more extensive than previously determined (Tukiainen et al., 1984). The unit comprises a wide $(100-700 \mathrm{~m})$ arcuate sheet, concave toward the centre of the intrusion and restricted to the area south of the Flinks Dal fault (Tukiainen, this report, fig. 19). The foyaite tapers and appears to terminate in south-east Motzfeldt. The relationship between this foyaite and the foyaitic rock types found in the inner part of the Flinks Dal Formation porphyritic nepheline syenite requires further study.

\section{The late sheeted intrusions}

Particular interest was attached to a partial ring dyke of laminated porphyritic syenite (Tukiainen, this report, fig. 19) discovered in south-east Motzfeldt this season. This unit had previously been found only in north-east Motzfeldt and had been tentatively classified as a nepheline-free variety of the Flinks Dal Formation foyaite of south-east Motzfeldt. The absence of nepheline and the abundance of mafic phases were explained by the deeper exposure levels in north-east Motzfeldt. This summer the nepheline-free unit was discovered at high elevations in south-east Motzfeldt. This and the field relations as now known clearly indicate that the unit is unrelated to the Flinks Dal Formation foyaite.

\section{Conclusions}

The 1984 field season was of particular value in furthering understanding of the complex geology of the Motzfeldt Centre. Definite correlations have been established between the syenites of the southern part of the centre and those of the north-east and south-east which were mapped earlier. The revised, more symmetrical geology of the centre (cf. Tukiainen, this report, fig. 19, and Bradshaw \& Tukiainen, 1984, fig. 34) correlated well with radiometric mapping of the area, proving the value of this technique in alkaline igneous terrains. Detailed mapping of the syenite boundaries has confirmed the approximately $6 \mathrm{~km}$ sinistral horisontal movement across the Flinks Dal fault.

It had been hoped to complete the survey of the centre during this season but bad weather hindered progress. Overall coverage was consequently restricted and further field studies are needed.

Acknowledgements. The author thanks NERC, United Kingdom, for financial support and also the members of the GGU Pyrochlore project, 1984, for their kind co-operation and invaluable field assistance. 


\title{
References
}

Armour-Brown, A., Tukiainen, T., Wallin, B., Bradshaw, C. \& Emeleus, C. H. 1983: Uranium exploration in South Greenland. Rapp. Grønlands geol. Unders. 115, 68-75.

Tukiainen, T., Bradshaw, C. \& Emeleus, C. H. 1984: Geological and radiometric mapping of the Motzfeldt Centre of the Igaliko Complex, South Greenland. Rapp. Grønlands geol. Unders. 120, 78-83.

Department of Geological Sciences, University of Durham, Science Laboratories, South Road, Durham, U.K.

\section{New observations on the easternmost extension of the Gardar supracrustals (Eriksfjord Formation), South Greenland}

\author{
Lotte Melchior Larsen and Tapani Tukiainen
}

During the 1984 field work in the Motzfeldt Centre of the Igaliko Complex, some of the remnants of the supracrustal rocks of the Eriksfjord Formation were investigated. These occur at several localities bordering the centre, and are also found as inclusions (roof rafts) of variable size within the syenites of the centre. These supracrustal rocks form the easternmost extension of the sandstones and lavas of the Eriksfjord Formation, the major part of which is found on the Narssaq peninsula to the west.

Some of the easterly remnants were described by Emeleus \& Harry (1970) who noted the occurrence of sandstone and volcanic breccia, agglomerate and lava flows and described two small agglomerate-filled volcanic plugs. Our observations extend those of Emeleus \& Harry (1970).

\section{New observations}

South-east Motzfeldt Centre. The southern part of the syenites in the area contains a roof raft of supracrustal rocks a little more than $1 \times 0.5 \mathrm{~km}$. The supracrustals occur at altitudes of 880 to 1490 metres with massive volcanics above $1160 \mathrm{~m}$. At two levels syenite sheets 20 and $140 \mathrm{~m}$ wide have intruded along the bedding planes. The raft is thus in an early state of disintegration. The supracrustals dip $10-20^{\circ}$ northwards, and the succession consists of about $40 \mathrm{~m}$ of volcanic rocks succeeded by around $100 \mathrm{~m}$ of grey and reddish quartzitic sandstone, followed by a massive sequence of about $400 \mathrm{~m}$ of volcanic rocks. The volcanics comprise thick flows of reddish brown trachytes, both feldsparphyric and aphyric, and flow-banded feldsparphyric felsic lavas. A thin unit with ignimbrite structure was also found. The sequence contains one basalt flow or sill about $30 \mathrm{~m}$ thick. The sandstones are cut in two places by irregular dyke-like bodies of dense, dark grey ultramafic rocks one of which is pillowed.

North of the major E-W sinistral fault in the south-east Motzfeldt Centre, small scattered supracrustal remnants occur in an area of about $1 \times 2 \mathrm{~km}$ at an altitude of about $1700 \mathrm{~m}$. The 